\title{
Tetragermanates of Strontium, Lead, and Barium of Formula Type $\mathrm{AB}_{4} \mathrm{O}_{9}$
}

\author{
Carl R. Robbins and Ernest M. Levin
}

(December 13, 1960)

\begin{abstract}
Three new tetragermanates, $\mathrm{SrGe}_{4} \mathrm{O}_{9}, \mathrm{PbGe}_{4} \mathrm{O}_{9}$, and $\mathrm{BaGe}_{4} \mathrm{O}_{9}$, of formula type $\mathrm{AB}_{4} \mathrm{O}_{9}$ were found. $\mathrm{BaTiGe}_{3} \mathrm{O}_{9}$, the germanium analog of the mineral silicate benitoite $\left(\mathrm{BaTiSi}_{3} \mathrm{O}_{9}\right)$ was prepared for study and comparison. Indexed X-ray powder diffraction patterns of the tetragermanates and of $\mathrm{BaTiGe}_{3} \mathrm{O}_{9}$ and $\mathrm{BaTiSi}_{3} \mathrm{O}_{9}$ show: (1) the tetragermanates are apparently isostructural; (2) the unit cell of $\mathrm{BaTiGe}_{3} \mathrm{O}_{9}$ at room temperature is related to that of the tetragermanates by a doubling of the $c$-axis of the latter; $(3)$ the tetragermanates and the metastable (room temperature) form of $\mathrm{BaTiGe}_{3} \mathrm{O}_{9}$ are apparently structurally similar to, but not isostructural with benitoite; (4) within its temperature stability range, $\mathrm{BaTiGe}_{3} \mathrm{O}_{9}$ appears to be isostructural with $\mathrm{BaTiSi}_{3} \mathrm{O}_{9}$

Densitỳ, melting point, and partial optical data for the tetragermanates were obtained.
\end{abstract}

\section{Introduction}

In the course of a study of the system $\mathrm{SrO}-\mathrm{GeO}_{2}$ [1] ${ }^{1}$ a new compound, $\mathrm{SrGe}_{4} \mathrm{O}_{9}$, of formula type $\mathrm{AB}_{4} \mathrm{O}_{9}$ was found.

Although the crystal chemistry of germanium is in many respects similar to that of silicon, no $\mathrm{AB}_{4} \mathrm{O}_{9}$ silicates are known. The mineral silicate benitoite, $\mathrm{BaTiSi}_{3} \mathrm{O}_{9}$, of formula type $\mathrm{ABC}_{3} \mathrm{O}_{9}$, one tetrasilicate [2] and three tetragermanates [3] of type $\mathrm{A}_{2} \mathrm{~B}_{4} \mathrm{O}_{9}$, and a series of mixed oxides of formula type $\mathrm{AB}_{2} \mathrm{C}_{2} \mathrm{O}_{9}$ [4] have been reported. Barium tetratitanate, $\mathrm{BaTi}_{4} \mathrm{O}_{9}[5]$ was the only example of an $\mathrm{AB}_{4} \mathrm{O}_{9}$ compound found in the literature.

Accordingly, it was of interest to attempt to synthesize other $\mathrm{AB}_{4} \mathrm{O}_{9}$ germanates for study and comparison. In addition to $\mathrm{SrO}: 4 \mathrm{GeO}_{2}$, mixtures in the ratios $\mathrm{CaO}: 4 \mathrm{GeO}_{2}, \mathrm{PbO}: 4 \mathrm{GeO}_{2}$, and $\mathrm{BaO}: 4 \mathrm{GeO}_{2}$ were prepared for study. It was known from previous work [6] that the compound $\mathrm{MgGe}_{4} \mathrm{O}_{9}$ does not exist.

The germanium compositional analog of benitoite, $\mathrm{BaTiGe}_{3} \mathrm{O}_{9}$, had been synthesized previously [7], and natural crystals of $\mathrm{BaTiSi}_{3} \mathrm{O}_{9}$ were obtained for comparison with $\mathrm{SrGe}_{4} \mathrm{O}_{9}$ and any other $\mathrm{AB}_{4} \mathrm{O}_{9}$ germanates found.

\section{Experimental Procedure}

\subsection{Materials and Methods}

Homogeneous starting mixtures were prepared from reagent grade $\mathrm{BaCO}_{3}, \mathrm{SrCO}_{3}, \mathrm{CaCO}_{3}, \mathrm{PbO}$, and $\mathrm{GeO}_{2}$ (quartz form). Mixtures were pressed into disks under a pressure of 10,000 psi. With the exception of the $\mathrm{PbO}: 4 \mathrm{GeO}_{2}$ mixture, the disks were calcined for 2 to 3 hours in platinum crucibles at $1000{ }^{\circ} \mathrm{C}$. The lead mixture was heated at tempera-

\footnotetext{
1 Figures in brackets indicate the literature references at the end of this paper.
}

tures up to $700{ }^{\circ} \mathrm{C}$. The process of mixing, pressing and calcining was repeated 3 times.

The volatility of $\mathrm{GeO}_{2}$ and $\mathrm{PbO}$ is negligible at the calcining temperatures employed. Samples treated at higher temperatures were enclosed in sealed platinum capsules. Melting point determinations were made by the quenching method. Temperatures were measured with a calibrated Pt-Pt 10 percent Rh thermocouple. Samples were examined with binocular and polarizing microscopes and by $\mathrm{X}$-ray powder diffractometry using Ni-filtered $\mathrm{Cu}$ radiation. High temperature X-ray studies were made with equipment described by Mauer and Bolz [8].

\subsection{Density Determination}

Since large crystals were not obtained in this study, the problem of determining the density of a small amount of fine powder was encountered. Approximate values were obtained with a Berman density balance on fragments of charges heated in sealed capsules for 4 hours. In addition, a theoretical optical density was calculated for each compound by applying the rule of Gladstone and Dale [9] to crystalline materials, as suggested by Larsen [10]. The specific refractivity formula of Gladstone and Dale is:

where

$$
(n-1) / d=K,
$$

$n$ is the average index of refraction, $d$ represents the density, and $K$ is the sum of products of the weight fractions of the oxides by their respective specific refractivities.

The average index was measured or calculated from measured extreme indices using the relationship $n=(2 \omega+\epsilon) / 3$, the equation for uniaxial substances. 
Specific refractivity values were taken from Larsen [10] with the exception of the value of $k=0.165$ for the $\alpha$-quartz form of $\mathrm{GeO}_{2}$. The latter was calculated from the data of Laubengayer and Morton [11].

\section{Results and Discussion}

Three new compounds, $\mathrm{SrGe}_{4} \mathrm{O}_{9}, \mathrm{PbGe}_{4} \mathrm{O}_{9}$, and $\mathrm{BaGe}_{4} \mathrm{O}_{9}$, were found. Table 1 lists the density balance, optical and X-ray density values obtained. Melting point data, unit cell dimensions and optical properties are given in table 2.

$\mathrm{CaGe}_{4} \mathrm{O}_{9}$ was not formed at temperatures up to $1,000{ }^{\circ} \mathrm{C}$, the maximum temperature to which the mixture was heated. X-ray diffraction patterns always showed $\mathrm{GeO}_{2}$ and an unidentified phase richer in $\mathrm{CaO}$ than the ratio $\mathrm{CaO}: 4 \mathrm{GeO}_{2}$.

TABLE 1. A comparison of density values for the $\mathrm{AB}_{4} \mathrm{O}_{9}$ germanates

\begin{tabular}{|c|c|c|c|}
\hline Compound & $\begin{array}{l}\text { Density } \\
\text { Balance }\end{array}$ & Optical & X-Ray \\
\hline & $\left(\mathrm{g} / \mathrm{cm}^{3}\right)$ & $\left(\mathrm{g} / \mathrm{cm}^{3}\right)$ & $\left(\mathrm{g} / \mathrm{cm}^{3}\right)$ \\
\hline $\begin{array}{l}\mathrm{SrGe}_{4} \mathrm{O}_{9} \ldots \ldots \\
\mathrm{PbGe}_{4} \mathrm{O}_{9} \ldots \\
\mathrm{BaGe}_{4} \mathrm{O}_{9} \ldots\end{array}$ & $\begin{array}{l}\text { a } 4.84 \\
\text { b } 5.89 \\
\text { s } 5.07\end{array}$ & $\begin{array}{l}4.85 \\
5.96 \\
5.11\end{array}$ & $\begin{array}{l}4.89 \\
5.94 \\
5.12\end{array}$ \\
\hline
\end{tabular}

a Sintered at $1200^{\circ} \mathrm{C}$ for 4 hours.

b Sintered at $650{ }^{\circ} \mathrm{C}$ for 4 hours.

TABLE 2. Some properties of the $\mathrm{AB}_{4} \mathrm{O}_{9}$ germanates

\begin{tabular}{|c|c|c|c|c|c|c|c|}
\hline \multirow{2}{*}{ Compound } & \multirow{2}{*}{ Melting Point } & \multirow{2}{*}{$\begin{array}{c}\text { Unit Cell } \\
\text { Dimensions }\end{array}$} & \multirow{2}{*}{$Z$} & \multirow{2}{*}{$\begin{array}{l}\text { X-Ray } \\
\text { Density }\end{array}$} & \multicolumn{3}{|c|}{ Optical Properties } \\
\hline & & & & & Character & Indices & $n$ of glass \\
\hline & ${ }^{\circ} \mathrm{C}$ & $A$ & & $\left(\mathrm{~g} / \mathrm{cm}^{3}\right)$ & & $( \pm .003)$ & $( \pm .003)$ \\
\hline $\mathrm{SrGe}_{4} \mathrm{O}_{9}$ & $1298 \pm 5^{\circ}$ & $\begin{array}{l}\text { Hex. } a=11.34 \\
\text { Hex } c=4.75\end{array}$ & 3 & 4. 89 & weakly birefringent....... & $\bar{\eta}=1.780$ & 1. 735 \\
\hline $\mathrm{PbGe}_{4} \mathrm{O}_{9-\ldots}$ & dissociates & Hex. $a=11.41$ & 3 & 5. 94 & anhedral, birefringent..... & $\bar{\eta}=1.800$ & 1. 776 \\
\hline $\mathrm{BaGe}_{4} \mathrm{O}_{9-\ldots}$ & $\begin{array}{l}\text { at } \sim 700^{\circ} . \\
1392 \pm 5^{\circ}\end{array}$ & $\begin{array}{l}\text { Hex. } c=4.75 \\
\text { Hex. } \mathrm{a}=11.61 \\
\text { Hex. } \mathrm{c}=4.74\end{array}$ & 3 & 5.12 & $\begin{array}{l}\text { anhedral, birefringent, uni- } \\
\text { axial negative. }\end{array}$ & $\begin{array}{l}\omega=1.797 \\
\epsilon=1.783\end{array}$ & 1. 746 \\
\hline
\end{tabular}

\subsection{Description of Compounds}

$\mathrm{SrGe}_{4} \mathrm{O}_{9}$. The compound $\mathrm{SrGe}_{4} \mathrm{O}_{9}$ melts congruently at $1298 \pm 5{ }^{\circ} \mathrm{C}$. It crystallizes in plates of irregular outline which show extremely low birefringence. Using the oil immersion method and white light, an average refractive index of 1.780 was observed. The optic sign could not be determined. The X-ray powder diffractometer pattern was indexed on the basis of a hexagonal unit cell with $a=11.34 \mathrm{~A}, c=4.75 \mathrm{~A}$, and $c / a=0.4189$. The theoretical X-ray density is $4.89 \mathrm{~g} / \mathrm{cm}^{3}$ and there are 3 molecules per unit cell. X-ray data for the compound are given in table 3 .

$\mathrm{PbGe}_{4} \mathrm{O}_{9}$. The compound $\mathrm{PbGe}_{4} \mathrm{O}_{9}$ was not observed by Speranskaya [12] in his recent study of the system $\mathrm{PbO}-\mathrm{GeO}_{2}$. It dissociates at approximately $700{ }^{\circ} \mathrm{C}$ to $\mathrm{GeO}_{2}$ (rutile form) and an unidentified crystalline phase. Crystals of $\mathrm{PbGe}_{4} \mathrm{O}_{9}$ obtained were unsuitable for detailed optical study. They were birefringent with an average refractive index of approximately 1.800. The compound was indexed ${ }^{2}$ on a hexagonal cell with $a=11.41 \mathrm{~A}, c=4.75 \mathrm{~A}$, and $c / a=0.4163$. The X-ray density is $5.94 \mathrm{~g} / \mathrm{cm}^{3}$ and $\mathrm{Z}=3$. $\mathrm{X}$-ray powder diffractometer data are given in table 4 .

2 Three very weak diffraction peaks, not indexable on the basis of this cell, were observed. Preliminary studies of the system $\mathrm{PbO}-\mathrm{GeO}_{2}$ suggest that they represent a trace of metastably formed $\mathrm{PbGeO}_{3}$.
TABLE 3. X-ray a powder diffraction data for $\mathrm{SrGe}_{4} \mathrm{O}_{9}$

\begin{tabular}{|c|c|c|c|c|}
\hline$h k l$ & dobs & $I / I_{0} \mathrm{~b}$ & $\frac{1}{d^{2} \mathrm{obs}}$ & $\frac{1^{\mathrm{e}}}{d^{2} \mathrm{cal}}$ \\
\hline 110 & $\begin{array}{r}A \\
\text { 5. } 67\end{array}$ & 26 & 0.0311 & 0.0311 \\
\hline $\begin{array}{l}001 \\
101 \\
111 \\
201 \\
300\end{array}$ & $\begin{array}{l}\text { 4. } 75 \\
\text { 4. } 28 \\
\text { 3. } 65 \\
\text { 3. } 42 \\
\text { 3. } 27\end{array}$ & $\begin{array}{r}8 \\
5 \\
92 \\
13 \\
7\end{array}$ & $\begin{array}{l}.0443 \\
.0547 \\
.0752 \\
.0857 \\
.0933\end{array}$ & $\begin{array}{l}.0443 \\
.0546 \\
.0754 \\
.0858 \\
.0934\end{array}$ \\
\hline $\begin{array}{l}211 \\
220 \\
301 \\
221 \\
002\end{array}$ & $\begin{array}{l}2.925 \\
2.834 \\
2.695 \\
2.435 \\
2.377\end{array}$ & $\begin{array}{r}55 \\
74 \\
100 \\
21 \\
6\end{array}$ & $\begin{array}{l}.1169 \\
.1245 \\
.1377 \\
.1686 \\
.1770\end{array}$ & $\begin{array}{l}.1169 \\
.1245 \\
.1376 \\
.1688 \\
.1770\end{array}$ \\
\hline $\begin{array}{l}311 \\
102 \\
112 \\
401 \\
410\end{array}$ & $\begin{array}{l}2.364 \\
2.310 \\
2.191 \\
2.182 \\
2.143\end{array}$ & $\begin{array}{l}6 \\
8 \\
4 \\
9 \\
7\end{array}$ & $\begin{array}{l}.1789 \\
.1874 \\
.2083 \\
.2101 \\
.2178\end{array}$ & $\begin{array}{l}.1791 \\
.1874 \\
.2082 \\
.2103 \\
.2179\end{array}$ \\
\hline $\begin{array}{l}321 \\
212 \\
411 \\
302 \\
330\end{array}$ & $\begin{array}{l}2.036 \\
2.002 \\
1.9544 \\
1.9239 \\
1.8960\end{array}$ & $\begin{array}{r}10 \\
15 \\
13 \\
6 \\
2\end{array}$ & $\begin{array}{l}.2414 \\
.2495 \\
.2618 \\
.2702 \\
.2799\end{array}$ & $\begin{array}{l}.2414 \\
.2497 \\
.2621 \\
.2704 \\
.2801\end{array}$ \\
\hline $\begin{array}{l}222 \\
312 \\
331 \\
402 \\
600\end{array}$ & $\begin{array}{l}1.8219 \\
1.7918 \\
1.7568 \\
1.7077 \\
1.6372\end{array}$ & $\begin{array}{r}19 \\
8 \\
14 \\
4 \\
14\end{array}$ & $\begin{array}{l}.3013 \\
.3115 \\
.3240 \\
.3429 \\
.3731\end{array}$ & $\begin{array}{l}.3015 \\
.3119 \\
.3244 \\
.3430 \\
.3735\end{array}$ \\
\hline 412 & 1. 5923 & 4 & .3944 & .3949 \\
\hline
\end{tabular}

s $\mathrm{Cu} \mathrm{K} \alpha$ Radiation.

b $I / I_{0}$ represents the intensity of the diffraction peak relative to the strongest peak. $c=4.75 \mathrm{~A}$. 
TABLe 4. X-ray a powder diffraction data for $\mathrm{PbGe}_{4} \mathrm{O}_{9}$

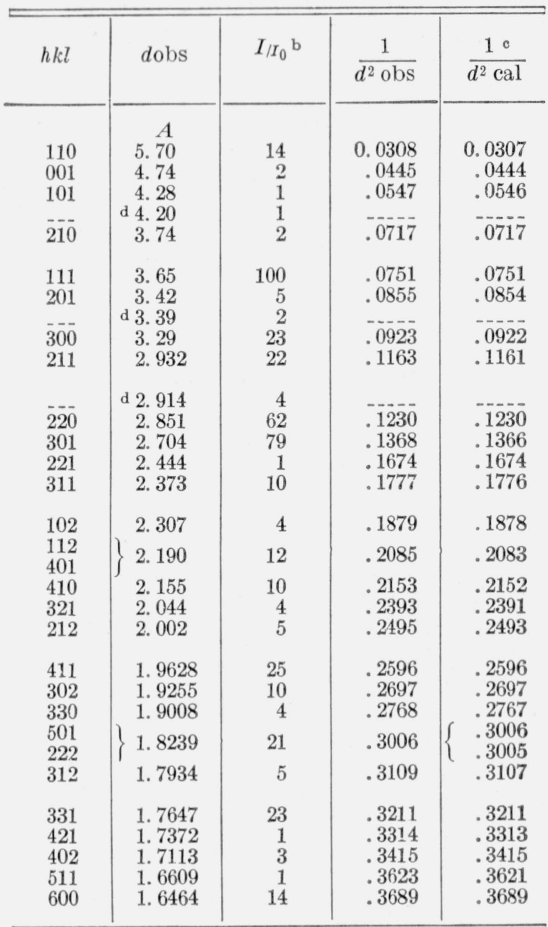

a CuK $\alpha$ radiation

b $I_{/ I_{0}}$ represents the intensity of the diffraction peak relative to the strongest peak.

. Calculated on the basis of the following unit cell dimensions: $a=11.41 \mathrm{~A}, c=4.75 \mathrm{~A}$.

d See discussion of $\mathrm{PbGe}_{4} \mathrm{O}$ in text.
Table 5. X-ray a powder diffraction data for $\mathrm{BaGe}_{4} \mathrm{O}_{9}$

\begin{tabular}{|c|c|c|c|c|}
\hline$h k l$ & dobs & $I_{/ I_{0}} \mathrm{~b}$ & $\frac{1}{d^{2} \mathrm{obs}}$ & $\frac{1^{\circ}}{d^{2} \mathrm{cal}}$ \\
\hline $\begin{array}{l}110 \\
001 \\
101 \\
111 \\
201\end{array}$ & $\begin{array}{r}A \\
5.80 \\
4.74 \\
4.28 \\
3.67 \\
3.44\end{array}$ & $\begin{array}{r}11 \\
2 \\
3 \\
100 \\
6\end{array}$ & $\begin{array}{r}0.0298 \\
.0446 \\
.0546 \\
.0743 \\
.0843\end{array}$ & $\begin{array}{r}0.0297 \\
.0446 \\
.0545 \\
.0743 \\
.0842\end{array}$ \\
\hline $\begin{array}{l}300 \\
211 \\
220 \\
301 \\
221\end{array}$ & $\begin{array}{l}3.35 \\
2.963 \\
2.899 \\
2.733 \\
2.473\end{array}$ & $\begin{array}{r}17 \\
25 \\
56 \\
86 \\
9\end{array}$ & $\begin{array}{l}.0893 \\
.1139 \\
.1190 \\
.1339 \\
.1635\end{array}$ & $\begin{array}{r}.0891 \\
.1139 \\
.1188 \\
.1337 \\
.1634\end{array}$ \\
\hline $\begin{array}{l}311 \\
002 \\
320 \\
102 \\
401 \\
410 \\
112\end{array}$ & $\begin{array}{l}\text { 2. } 401 \\
\text { 2. } 368 \\
\text { 2. } 306 \\
\text { 2. } 219 \\
\text { 2. } 192\end{array}$ & $\begin{array}{r}4 \\
8 \\
9 \\
4 \\
4 \\
11\end{array}$ & $\begin{array}{l}.1735 \\
.1783 \\
.1881 \\
.2032 \\
.2081\end{array}$ & $\left\{\begin{array}{r}.1733 \\
.1783 \\
.1861 \\
.1882 \\
.2029 \\
.2079\end{array}\right.$ \\
\hline $\begin{array}{l}202 \\
321 \\
212 \\
411 \\
330\end{array}$ & $\begin{array}{l}\text { 2. } 142 \\
\text { 2. } 072 \\
2.010 \\
\text { 1. } 9893 \\
\text { 1. } 9344\end{array}$ & $\begin{array}{r}2 \\
5 \\
10 \\
18 \\
11\end{array}$ & $\begin{array}{l}.2180 \\
.2329 \\
.2475 \\
.2527 \\
.2673\end{array}$ & $\begin{array}{l}.2179 \\
.2326 \\
.2475 \\
.2524 \\
.2673\end{array}$ \\
\hline 302 & 1. 9344 & 11 & .2673 & \\
\hline $\begin{array}{l}501 \\
222\end{array}$ & $\begin{array}{l}\text { 1. } 8499 \\
\text { 1. } 8349\end{array}$ & $\begin{array}{r}2 \\
22\end{array}$ & $\begin{array}{r}.2922 \\
.2970\end{array}$ & $\begin{array}{l}.2920 \\
.2970\end{array}$ \\
\hline $\begin{array}{l}312 \\
510\end{array}$ & 1. 8046 & 6 & .3070 & .3069 \\
\hline $\begin{array}{l}331 \\
402\end{array}$ & $\begin{array}{l}\text { 1. } 7905 \\
\text { 1. } 7232\end{array}$ & $\begin{array}{r}25 \\
2\end{array}$ & $\begin{array}{r}.3119 \\
.3368\end{array}$ & $\begin{array}{r}.3118 \\
.3366\end{array}$ \\
\hline 600 & 1. 6746 & 17 & .3566 & .3563 \\
\hline
\end{tabular}

a $\mathrm{Cu} \mathrm{K} \alpha$ radiation

b $I / I_{0}$ represents the intensity of the diffraction peak relative to the strongest peak.

o Calculated on the basis of the following unit cell dimensions: $a=11.61 \mathrm{~A}, c=4.74 \mathrm{~A}$.

TABLE 6. X-ray a powder diffraction data for $\mathrm{BaTiGe}_{3} \mathrm{O}_{9}{ }^{\mathrm{b}}$ at room temperature

\begin{tabular}{|c|c|c|c|c|}
\hline$h k l$ & dobs & $I / I_{0}{ }^{\circ}$ & $\frac{1}{d^{2} \mathrm{obs}}$ & $\frac{1 \mathrm{~d}}{d^{2} \mathrm{cal}}$ \\
\hline $\begin{array}{l}110 \\
002 \\
102 \\
112 \\
202\end{array}$ & $\begin{array}{r}A \\
5.85 \\
5.01 \\
4.49 \\
3.81 \\
3.57\end{array}$ & $\begin{array}{r}7 \\
6 \\
3 \\
65 \\
5\end{array}$ & $\begin{array}{r}0.0292 \\
.0398 \\
.0496 \\
.0690 \\
.0787\end{array}$ & $\begin{array}{r}0.0291 \\
.0398 \\
.0495 \\
.0689 \\
.0786\end{array}$ \\
\hline $\begin{array}{l}300 \\
301 \\
212 \\
220 \\
302\end{array}$ & $\begin{array}{l}\text { 3. } 39 \\
\text { 3. } 21 \\
\text { 3. } 05 \\
2.928 \\
2.803\end{array}$ & $\begin{array}{r}13 \\
28 \\
3 \\
50 \\
100\end{array}$ & $\begin{array}{l}.0872 \\
.0973 \\
.1078 \\
.1166 \\
.1273\end{array}$ & $\begin{array}{l}.0872 \\
.0972 \\
.1077 \\
.1163 \\
.1271\end{array}$ \\
\hline $\begin{array}{l}222 \\
004 \\
312 \\
104 \\
303\end{array}$ & $\begin{array}{l}2.531 \\
2.505 \\
2.453 \\
2.430 \\
2.378\end{array}$ & $\begin{array}{r}4 \\
21 \\
2 \\
2 \\
2\end{array}$ & $\begin{array}{l}.1561 \\
.1594 \\
.1662 \\
.1694 \\
.1769\end{array}$ & $\begin{array}{l}.1561 \\
.1594 \\
.1658 \\
.1691 \\
.1769\end{array}$ \\
\hline $\begin{array}{l}114 \\
402 \\
204 \\
410 \\
411\end{array}$ & $\begin{array}{l}2.305 \\
2.264 \\
2.247 \\
2.218 \\
2.164\end{array}$ & $\begin{array}{r}16 \\
3 \\
3 \\
13 \\
13\end{array}$ & $\begin{array}{l}.1882 \\
.1951 \\
.1981 \\
.2033 \\
.2135\end{array}$ & $\begin{array}{l}.1884 \\
.1949 \\
.1981 \\
.2035 \\
.2135\end{array}$ \\
\hline $\begin{array}{l}214 \\
412 \\
304 \\
330 \\
224\end{array}$ & $\begin{array}{l}2.097 \\
2.028 \\
2.015 \\
1.956 \\
1.905\end{array}$ & $\begin{array}{r}4 \\
14 \\
3 \\
7 \\
15\end{array}$ & $\begin{array}{l}.2274 \\
.2432 \\
.2463 \\
.2615 \\
.2756\end{array}$ & $\begin{array}{l}.2272 \\
.2433 \\
.2466 \\
.2616 \\
.2757\end{array}$ \\
\hline $\begin{array}{l}312 \\
413 \\
332\end{array}$ & $\begin{array}{l}1.874 \\
1.848 \\
1.822\end{array}$ & $\begin{array}{r}3 \\
6 \\
11\end{array}$ & $\begin{array}{r}.2849 \\
.2928 \\
.3012\end{array}$ & $\begin{array}{l}.2853 \\
.2931 \\
.3015\end{array}$ \\
\hline
\end{tabular}

Cu K $\alpha$ Radiation

b This specimen was prepared by heating a portion of the calcined starting mixture in a sealed platinum capsule at $1150^{\circ} \mathrm{C}$ for 5 days, and quenching it. - $I_{/} I_{0}$ represents the intensity of the diffraction peak relative to the strongest peak.

d These values were calculated on the basis of the following unit cell dimensions: $a=11.73 \mathrm{~A}$ and $c=10.02 \mathrm{~A}$. 
$\mathrm{BaTiSi}_{3} \mathrm{O}_{9}$. Zachariasen [14] determined the crystal structure of $\mathrm{BaTiSi}_{3} \mathrm{O}_{9}$. He found that the unit cell contained 2 molecules and had the following dimensions: $a=6.60 \pm 0.01 \mathrm{~A}, c=9.71 \pm 0.01 \mathrm{~A}$. The space group is $\mathrm{D}_{3 \mathrm{~h}}^{2}(\mathrm{P} \overrightarrow{\mathrm{b}} \mathrm{c} 2)$ and the calculated density is $3.73 \mathrm{~g} / \mathrm{cm}^{3}$.

The compound was interesting because it was the only known member of the ditrigonal-bipyramidal symmetry class, and because it afforded the only known example of $\mathrm{SiO}_{4}$ tetrahedra linked in rings of composition $\mathrm{Si}_{3} \mathrm{O}_{9}$. Subsequently, this structural group has been found in several other silicates. A projection of the structure (after Bragg [15]) on the 0001 plane is shown in figure 1. Both $\mathrm{Ba}$ and $\mathrm{Ti}$ are surrounded by 6 oxygen atoms. There are two layers of rings in the length of the $c$-axis.

X-ray powder diffractometer data (table 7) were obtained from natural crystals of $\mathrm{BaTiSi}_{3} \mathrm{O}_{9}$ from St. Benito Co., California (USNM \#C3938). The compound was indexed on the basis of Zachariasen's unit cell using the cell dimensions obtained in this study.

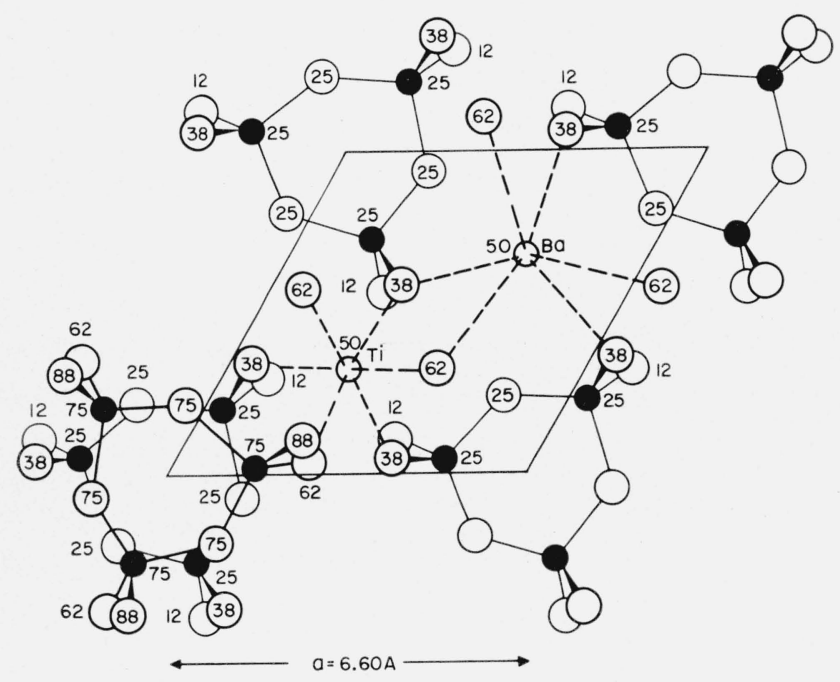

Figure 1. The structure of benitoite, $\mathrm{BaTiSi}_{3} \mathrm{O}_{9}$ (after Bragg). Only atoms on either side of the reflection plane at height 25 are shown, except in the bottom lefthand corner. rings.

\subsection{Structural Considerations}

Unit cell dimensions of the $\mathrm{AB}_{4} \mathrm{O}_{9}$ germanates and of $\mathrm{BaTiGe}_{3} \mathrm{O}_{9}$ and $\mathrm{BaTiSi}_{3} \mathrm{O}_{9}$ are summarized in table 8, and schematic, partial X-ray diffraction patterns are shown in figure 2 .

The $\mathrm{AB}_{4} \mathrm{O}_{9}$ germanates are apparently isostructural, having a $c$-axis of $4.75 \mathrm{~A}$ and an $a$-axis varying from 11.34A for $\mathrm{SrGe}_{4} \mathrm{O}_{9}$ through 11.61A for $\mathrm{BaGe}_{4} \mathrm{O}_{9}$, with 3 molecules per unit cell. If certain reflections of the powder diffraction patterns are omitted, the
TABLE 7. X-ray a powder diffraction data for benitoite $\left(\mathrm{BaTiSi}_{3} \mathrm{O}_{9}\right)$ b

\begin{tabular}{|c|c|c|c|c|}
\hline hkl & dobs & $\mathrm{I} / \mathrm{I}_{0}{ }^{\circ}$ & $\frac{1}{d^{2} \mathrm{obs}}$ & $\frac{1 \mathrm{~d}}{\mathrm{~d}^{2} \mathrm{cal}}$ \\
\hline $\begin{array}{l}100 \\
002 \\
102 \\
110 \\
111\end{array}$ & $\begin{array}{c}A \\
5.74 \\
4.87 \\
3.72 \\
3.32 \\
3.14\end{array}$ & $\begin{array}{r}18 \\
5 \\
100 \\
38 \\
14\end{array}$ & $\begin{array}{r}0.0304 \\
.0421 \\
.0724 \\
.0909 \\
.1014\end{array}$ & $\begin{array}{r}0.0302 \\
.0421 \\
.0723 \\
.0907 \\
.1012\end{array}$ \\
\hline $\begin{array}{l}200 \\
112 \\
202 \\
004 \\
104\end{array}$ & $\begin{array}{l}2.873 \\
2.742 \\
2.475 \\
2.438 \\
2.245\end{array}$ & $\begin{array}{r}23 \\
74 \\
8 \\
12 \\
12\end{array}$ & $\begin{array}{l}.1211 \\
.1330 \\
.1633 \\
.1683 \\
.1985\end{array}$ & $\begin{array}{l}.1210 \\
1328 \\
.1630 \\
.1683 \\
.1986\end{array}$ \\
\hline $\begin{array}{l}210 \\
211 \\
212 \\
114 \\
300\end{array}$ & $\begin{array}{l}2.172 \\
2.120 \\
1.984 \\
1.965 \\
1.916\end{array}$ & $\begin{array}{r}25 \\
14 \\
9 \\
28 \\
21\end{array}$ & $\begin{array}{l}.2120 \\
.2225 \\
.2540 \\
.2590 \\
.2723\end{array}$ & $\begin{array}{l}.2117 \\
.2222 \\
.2538 \\
.2590 \\
.2722\end{array}$ \\
\hline $\begin{array}{l}204 \\
302 \\
220 \\
214 \\
310\end{array}$ & $\begin{array}{l}1.859 \\
1.783 \\
1.659 \\
1.622 \\
1.594\end{array}$ & $\begin{array}{r}20 \\
17 \\
4 \\
12 \\
4\end{array}$ & $\begin{array}{l}.2894 \\
.3147 \\
.3632 \\
.3801 \\
.3937\end{array}$ & $\begin{array}{l}.2893 \\
.3143 \\
.3629 \\
.3800 \\
.3931\end{array}$ \\
\hline $\begin{array}{l}222 \\
106\end{array}$ & $\begin{array}{l}\text { 1. } 571 \\
\text { 1. } 567\end{array}$ & $\begin{array}{r}4 \\
11\end{array}$ & $\begin{array}{l}.4053 \\
.4072\end{array}$ & $\begin{array}{r}.4050 \\
.4072\end{array}$ \\
\hline
\end{tabular}

a $\mathrm{Cu} \mathrm{K} \alpha$ radiation.

b Data obtained from natural erystals of $\mathrm{BaTiSi}_{3} \mathrm{O}_{\ominus}$ from St. Benito Co., California (USNM \#C3938)

ornia (USNM \#C3938).
${ }^{\circ} \mathrm{I} / \mathrm{I}_{0}$ represents the intensity of the diffraction peak relative to the strongest peak

d Calculated on the basis of following unit cell dimensions: $a=6.64 \mathrm{~A}, c=9.75 \mathrm{~A}$. Zachariasen [14] reported the following values: $a=6.60 \pm 0.01 \mathrm{~A}, c=9.71 \pm 0.01 \mathrm{~A}$.

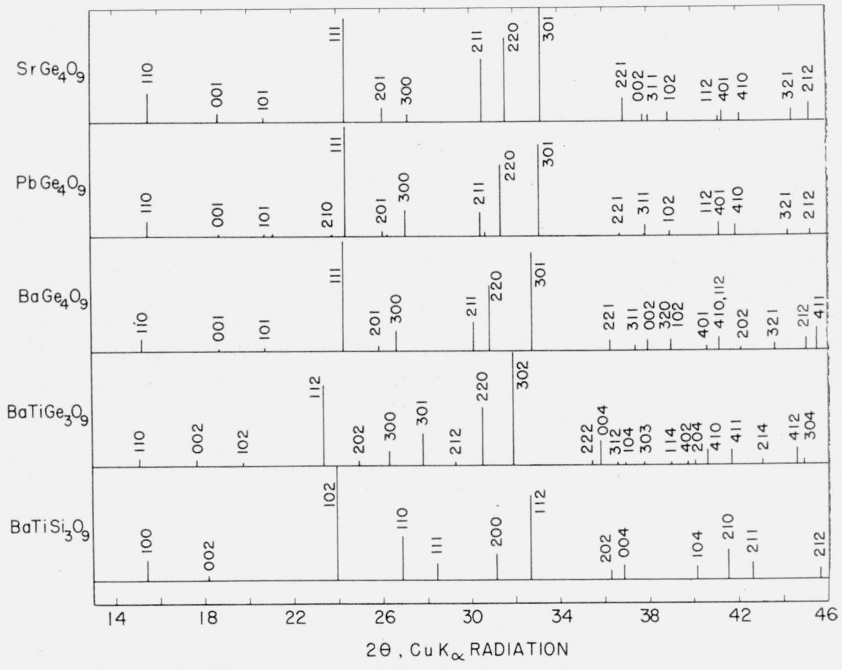

FIGURE 2. Schematic partial X-ray diffractometer patterns of the $\mathrm{AB}_{4} \mathrm{O}_{9}$ Germanates, $\mathrm{BaTiGe}_{3} \mathrm{O}_{9}$ (room temperature form) and $\mathrm{BaTiSi}_{3} \mathrm{O}_{9}$.

101, 201 and 211 for example, the $\mathrm{AB}_{4} \mathrm{O}_{9}$ germanates may be indexed on the benitoite $\left(\mathrm{BaTiSi}_{3} \mathrm{O}_{9}\right)$ cell.

The $\mathrm{AB}_{4} \mathrm{O}_{9}$ germanates are related to the room temperature form (metastable) of $\mathrm{BaTiGe}_{3} \mathrm{O}_{9}$ by a doubling of the $c$-axis of the former. If certain reflections of the room temperature diffractometer pattern of $\mathrm{BaTiGe}_{3} \mathrm{O}_{9}$ are omitted, the 102, 202, and 212 , for example, this form may be indexed on the benitoite cell. However, within its temperature stability range $\left(1132^{\circ} \pm 10^{\circ} \mathrm{C}\right.$ to $\left.1235^{\circ} \pm 10^{\circ} \mathrm{C}\right)$, 
TABLE 8. A comparison of the unit cell dimensions of the $\mathrm{AB}_{4} \mathrm{O}_{9}$ germanates and of $\mathrm{BaTiGe}_{3} \mathrm{O}_{9}$ and $\mathrm{BaTiSi}_{3} \mathrm{O}_{9}$

\begin{tabular}{|c|c|c|c|}
\hline Compound & $a$ & $c$ & Z \\
\hline $\begin{array}{l}\mathrm{SrGe}_{4} \mathrm{O}_{9} \\
\mathrm{PbGe}_{4} \mathrm{O}_{9} \\
\mathrm{BaGe}_{4} \mathrm{O}_{9} \\
\mathrm{BaTiGe}_{3} \mathrm{O}_{9} \mathrm{a}^{\mathrm{a}} \\
\mathrm{BaTiGe}_{3} \mathrm{O}_{9} \mathrm{~b} \\
\mathrm{BaTiSi}_{3} \mathrm{O}_{9}{ }^{\circ}{ }_{2}\end{array}$ & $\begin{array}{c}A \\
11.34 \\
11.41 \\
11.61 \\
11.73 \\
6.8 \\
6.60\end{array}$ & $\begin{array}{c}A \\
4.75 \\
4.75 \\
4.74 \\
10.02 \\
10.0 \\
9.71\end{array}$ & $\begin{array}{l}3 \\
3 \\
3 \\
6 \\
6 \\
2 \\
2\end{array}$ \\
\hline
\end{tabular}

a Measured at room temperature.

b Measured at $1160^{\circ} \pm 20^{\circ} \mathrm{C}$

- Zachariasen's values [14].

these reflections are not present, and $\mathrm{BaTiGe}_{3} \mathrm{O}_{9}$ is apparently isostructural with $\mathrm{BaTiSi}_{3} \mathrm{O}_{9}$. Corresponding reflections in the patterns of $\mathrm{SrGe}_{4} \mathrm{O}_{9}$ and $\mathrm{BaGe}_{4} \mathrm{O}_{9}$ did not disappear with heating, and no change was observed in the pattern of $\mathrm{BaTiSi}_{3} \mathrm{O}_{9}$ at temperatures up to $11600^{\circ} \pm 20^{\circ} \mathrm{C}$.

Since the $\mathrm{AB}_{4} \mathrm{O}_{9}$ germanates appear to be structurally very similar to $\mathrm{BaTiSi}_{3} \mathrm{O}_{9}$, rings of $\mathrm{GeO}_{4}$ tetrahedra of composition $\mathrm{Ge}_{3} \mathrm{O}_{9}$ are most probably their dominant structural unit. Since germanium may have either 4 -fold or 6 -fold coordination with respect to oxygen, the fourth germanium atom would occupy the titanium position of $\mathrm{BaTiSi}_{3} \mathrm{O}_{9}$, in octahedral coordination. Thus the formula $\mathrm{BaGe}_{4} \mathrm{O}_{9}$ should, perhaps more correctly, be written as $\mathrm{BaGeGe}_{3} \mathrm{O}_{9}$.

The observed differences between $\mathrm{BaTiGe}_{3} \mathrm{O}_{9}$, $\mathrm{BaTiSi}_{3} \mathrm{O}_{9}$ and the $\mathrm{AB}_{4} \mathrm{O}_{9}$ germanates result primarily from a difference in size between $\mathrm{Ti}$ and $\mathrm{Ge}$ (in octahedral coordination) and between $\mathrm{Si}$ and tetrahedrally coordinated Ge. In the lower left corner of figure 1 it is seen that the upper $\mathrm{Si}_{3} \mathrm{O}_{9}$ ring does not lie directly above the lower one, and two units are required in the length of the $c$-axis of $\mathrm{BaTiSi}_{3} \mathrm{O}_{9}$. A similar rotation of a corresponding $\mathrm{Ge}_{3} \mathrm{O}_{9}$ ring presumably is the reason for the doubling of the $c$-axis of the $\mathrm{BaGe}_{4} \mathrm{O}_{9}$ structure when one $\mathrm{Ti}$ is substituted for one Ge to form $\mathrm{BaTiGe}_{3} \mathrm{O}_{9}$. It should be noted that the long diagonal of figure 1 is of the order of magnitude of the $11 \mathrm{~A} a$-axis of the $\mathrm{AB}_{4} \mathrm{O}_{9}$ germanates and metastable $\mathrm{BaTiGe}_{3} \mathrm{O}_{9}$. Apparently the substitution of the larger $\mathrm{Ge}_{3} \mathrm{O}_{9}$ groups for $\mathrm{Si}_{3} \mathrm{O}_{9}$ groups requires that the diagonal of the silicate cell become the $a$-axis of the germanate cell. Within the temperature stability range of $\mathrm{BaTiGe}_{3} \mathrm{O}_{9}$ this distortion is relieved, and the compound has the $6 \mathrm{~A}$ $a$-axis of the silicate.

Preliminary intensity calculations indicate that the preceding structural assumptions for the $\mathrm{AB}_{4} \mathrm{O}_{9}$ germanates are correct. Suitable single crystals of $\mathrm{BaGe}_{4} \mathrm{O}_{9}$ have been obtained, and a detailed study of the structure of the compound is in progress.

(Paper 65A2-95)

\section{Summary}

Three new compounds, $\mathrm{SrGe}_{4} \mathrm{O}_{9}, \mathrm{PbGe}_{4} \mathrm{O}_{9}$ and $\mathrm{BaGe}_{4} \mathrm{O}_{9}$, of formula type $\mathrm{AB}_{4} \mathrm{O}_{9}$, have been synthesized. These tetragermanates appear to be isostructural. They are apparently structurally similar to, but not isostructural with, $\mathrm{BaTiSi}_{3} \mathrm{O}_{9}$.

The compound $\mathrm{BaTiGe}_{3} \mathrm{O}_{9}$ is metastable at room temperature. The metastable form is related to the $\mathrm{AB}_{4} \mathrm{O}_{9}$ germanates by a doubling of the $c$-axis of the latter. Metastable $\mathrm{BaTiGe}_{3} \mathrm{O}_{9}$ is apparently structurally similar to, but not isostructural with, $\mathrm{BaTiSi}_{3} \mathrm{O}_{9}$. It appears to be a structural link between the $\mathrm{AB}_{4} \mathrm{O}_{9}$ germanates and $\mathrm{BaTiSi}_{3} \mathrm{O}_{9}$, having the 11A $a$-axis of the former, and the two layers of rings in the length of the $c$-axis of the latter.

Within its temperature stability range, $\mathrm{BaTiGe}_{3} \mathrm{O}_{9}$ is apparently isostructural with $\mathrm{BaTiSi}_{3} \mathrm{O}_{9}$.

The authors are grateful to H. F. McMurdie for helpful discussions of the work, and to Helen Ondik and Alvin Perloff for assistance with the intensity calculations.

\section{References}

[1] C. R. Robbins and E. M. Levin, The System $\mathrm{SrO}-\mathrm{GeO}_{2}$, paper in preparation.

[2] F. C. Kracek, N. L. Bowen, and G. W. Morey, Equilibrium relations and factors influencing their determination in the system $\mathrm{K}_{2} \mathrm{SiO}_{3}-\mathrm{SiO}_{2}$, J. Phys. Chem. 41, 1183-1193 (1937).

[3] Gmelins Handbuch 30, 332 (1931).

[4] Bengt Aurivillius, Mixed bismuth oxides with layer lattices, ARKIV Für Kemi, 1, [No. 54] 463-480 (1950).

[5] D. E. Rase and R. Roy, Phase equilibrium in the system $\mathrm{BaO}^{-\mathrm{TiO}_{2}}$, J. Am. Ceramic Soc., 38, [No. 3] 110 (1955).

[6] C. R. Robbins and E. M. Levin, The system magnesium oxide-germanium dioxide, Am. J. Sci. 25\%, 63-70 (1959).

[7] C. R. Robbins, The compound $\mathrm{BaTiGe}_{3} \mathrm{O}_{9}$, J. Am. Ceramic Soc., in press

[8] F. A. Mauer and L. H. Bolz, Thermal expansion of Cermet components by high temperature X-ray diffraction, NBS Report 3148 (1953).

[9] J. H. Gladstone and T. P. Dale, Researches on the refraction, dispersion, and sensitiveness of liquids, Roy. Soc. London Philos. Trans., 153, 337 (1864).

[10] E. S. Larsen and H. Berman, The microscopic determination of the nonopaque minerals, U.S. Geological Survey Bull, 848, p. 31 (U.S. Government Printing Office, 1934).

[11] A. W. Laubengayer and D. S. Morton, The polymor phism of germanium dioxide, J. Am. Chem. Soc. 54, 2303-2320 (1932).

[12] E. I. Speranskaya, System $\mathrm{PbO}-\mathrm{GeO}_{2}$, Izvest. Akad. Nauk S.S.S.R., Otdel. Khim. Nauk, 162-3 (1959).

[13] V. M. Goldschmidt, Zur Kristallchemie des Germaniums, Nachr. Ges. Wiss. Göttingen, Math.-Phys. Klasse, 184-190 (1931).

[14] W. H. Zachariasen, The crystal structure of benitoite, $\mathrm{BaTiSi}_{3} \mathrm{O}_{9}$, Z. Krist., $\boldsymbol{7 4}, 139-146$ (1930).

[15] W. L. Bragg, Atomic Structure of Minerals, p. 181 (Cornell University Press, Ithaca, New York, 1937). 


\section{Publications of the National Bureau of Standards}

\section{Selected Abstracts}

\author{
On Stokes flow about a torus, W. H. Pell and L. E. \\ Payne, Mathematika 7, 78-92 (1960).
}

This is the third of a series of papers on the Stokes (slow viscous) flow about axially symmetric bodies immersed in a uniform flow parallel to the axis of symmetry. The flow itself then has axial symmetry and is amenable to attack by the generalized axially symmetric potential theory of A. Weinstein. In this particular paper the flow in multiply connected regions is considered and, in particular, the problem of flow about a torus is solved. The mathematical problem which characterizes the flow does not have a unique solution. Uniqueness is insured by the physical condition that the pressure be continuous throughout the flow field.

The Stokes flow about a spindle, W. H. Pell and L. E. Payne, Quart. Appl. Math. 18, 257-262 (1960).

This is a continuation of earlier work by the same authors. The methods of the generalized axially symmetric potential theory of A. Weinstein and certain representation theorems of L. Payne for the solution of repeated operator equations are applied to the solution of the Stokes (slow) flow about a spindle-shaped body. The stream function of the flow is found and an expression is given for the drag of the body.

A quantitative formulation of Sylvester's law of inertia, A. M. Ostrowski, Natl. Acad. Sci. Proc. 45, No. 5, 740-744 (May 1959).

If an Hermitian form is transformed by a general linear transformation, bounds for the factors by which the eigenvalues are multiplied, can be indicated that depend only on the transformation used.

A comparison of atomic beam frequency standards, R. E. Beehler, R. C. Mockler, and C. S. Snider, Nature 187, 681-682 (August 20, 1960).

Standard frequencies obtained from various cesium atomic beam frequency standards have been compared in a number of instances. The results of Holloway, et al, showed agreement to about $2 \times 10^{-10}$ between the commercial beam standards developed and manufactured by the National Company and the atomic standards at the National Physical Laboratory, Teddington, England.

Two dissimilar beam standards at the National Bureau of Standards have been compared over the last several months. Their frequencies agree to within $\pm 1.5 \times 10^{-11}$ (standard deviation of the mean for the comparisons and estimated uncertainty due to effects of pertinent parameters).

Maser frequency stability, R. C. Mockler and J. A. Barnes, Proc. 13th Annual Frequency Control Symp., 583-595 (May 12-14, 1959).

The effort of the Bureau of Standards in maser work has been directed toward the attainment of high frequency stability for extended periods of time. A maser stabilized frequency multiplier chain has been controlled to $1 \times 10^{-11}$ for periods of 6 hours. These preliminary measurements and tests indicate that the maser can be held within narrow frequency limits for periods of weeks with simple modifications. The masers have been employed to study frequency multiplier and crystal oscillator stability. The data have enabled us to make some predictions of the behavior of extremely long atomic beam machines.
Thermal voltage converters for accurate voltage measurements to 30 megacycles per second, F. L. Hermach and E. S. Williams, Commun. Electron, AIEE, No. 49, 200-206 (July 1960).

Thermal voltage converters, each consisting of a deposited carbon resistor in series with a thermoelement in a coaxial line, have been developed for measurements of rms voltages from 1 to 200 volts. Their configuration permits an extended frequency range and makes it possible to compute the effect of residual reactances. Extensive tests indicate satisfactory agreement with computed ac-dc differences to $40 \mathrm{mc}$.

These voltage converters are ordinarily used to make ac-de tests of other thermocouple instruments, but can be used for a-c measurements as well. They are inexpensive and easy to construct. An accuracy of $0.1 \%$ or better is possible to at least $10 \mathrm{mc}$ and $0.2 \%$ at $30 \mathrm{mc}$.

Influence of earth curvature and the terrestrial magnetic field on VLF propagation, J. R. Wait and K. Spies, J. Geophys. Research 65, 2325-2331 (Aug. 1960).

An account is given of some recent work on the mode theory of V.L.F. ionospheric propagation. Attention is confined to the behavior of the attentuation coefficient of the dominant mode. The ionosphere is assumed to be a sharply bounded and homogeneous ionized medium. It is indicated that earth curvature increases the attenuation rate by as much as a factor of 2 as compared with corresponding attenuation for a flat earth. The influence of the earth's magnetic field is also shown to be important. In fact propagation paths from east-to-west suffer much greater attenuation than for westto-east paths. The theoretical results in the present paper appear to agree quite well with the experimental data of W. L. Taylor.

Charge transfer and electron production in $\mathrm{H}+\mathrm{H}$ collision, D. G. Hummer, R. F. Stebbings, W. L. Fite, and L. M. Branscomb, Phys. Rev. 2, 668-670 (July 1960).

The cross sections for charge transfer and electron production in collisions between hydrogen atoms and hydrogen negative ions $\left(\mathrm{H}^{-}\right)$have been measured over the energy range 100 ev to 40,000 ev using modulated atomic beam techniques in a cross beam experiment. Agreement of the experimental results with the perturbed stationary states calculation of Dalgarno and McDowell for charge transfer is quite satisfactory. Considerable discrepancy between available theory and experimental results occurs for the electron production cross section.

Variational treatment of electron-hydrogen atom elastic scattering, S. Geltman, Phys. Rev. 119, No. .4, 1283-1290 (Aug. 1960).

The Hulthén-Kohn variational method is applied to the elastic scattering of electrons by hydrogen atoms. The trial function used is of a non-separable form, allows for the virtual excitation of the $2 \mathrm{~s}$ and $3 \mathrm{~s}$ states, and contains a scaling parameter which is allowed to vary. The resulting scattering lengths and S, P, and D singlet and triplet phase shifts are compared with the results of other calculations, and reasons are given for expecting them to be of greatly improved accuracy. 
Thermodynamic structure of the outer solar atmosphere. VI. Effect of departures from the Saha equation on inferred properties of low chromosphere, S. R. Pottasch and R. N. Thomas, Astrophys. J. 132, 195-201 (July 1960).

We apply the methodology of our preceding treatment of the Saha equation under conditions of high Lyman continuous opacity, to a re-analysis of the continuous emission from the lowest chromosphere. The result is a greatly-steepened $\mathrm{T}_{\mathrm{e}}$-gradient, relative to the results of an earlier analysis based on the neglect of non-LTE effects.

Relationship between red auroral arcs and ionospheric recombination. G. A. M. King and F. E. Roach, J. Research NBS 65D, No. 2, 32 (1960).

A "monochromatic" (6300 A) auroral arc, observed photometrically to be north of Boulder, Colo., has been identified with oblique echoes on ionograms taken near Boulder. The auroral emission is explained in terms of a great enhancement of ionospheric recombination. The recombination process is shown to depend on the density of molecular nitrogen in the ionospheric $F$ region; the change in nitrogen density during and after auroral activity, responsible for the change in recombination rate, is ascribed to the combined effects of heating and mixing of the atmosphere at the lower ionospheric heights.

The characteristic energy losses of electrons in carbon, L. B. Leder and J. A. Suddeth, J. Appl. Phys. 8, 1422-1426 (August 1960).

The values reported for the characteristic energy losses of electrons in carbon vary by as much as $50 \%$. In an attempt to resolve this discrepancy the electron energy losses have been remeasured for evaporated carbon and natural graphite, and it is found that there is a large difference for these two forms of carbon. Electron diffraction patterns of evaporated carbon show it to be highly amorphous. Annealing of the films causes growth of the crystallites, and also an increase of the energy loss toward the loss values for graphite. It is shown by calculation that the difference in the energy losses for the two forms is due to a difference in density, and that annealing increases the density of the evaporated carbon and, therefore, the energy loss value.

Calibration of five gamma-emitting nuclides for emission rate, J. M. R. Hutchinson, NBS TNY1 (PB161572) (1960) 75 cents.

Mercury-203 and Niobium-95 were calibrated by a $4 \pi \beta-\gamma$ coincidence method for $\gamma$-emission rate, Zinc- 65 by comparison with the $1.12 \mathrm{Mev}$ peak of Scandium-46, Sodium-22 by a $\gamma$-annihilation-quanta coincidence method and by a triple coincidence method, and Strontium-85 by $x-\gamma$ coincidence counting. The accuracy of the calibration in all cases was \pm 2 percent. The half-life of the isomeric state of Rubidium85 was measured and found to be .98 microseconds.

Fast counting of alpha particles in air ionization chambers, Z. Bay, F. D. McLernon, and P. A. Newman. J. Reseacrh NBS 65C, No. 1, 51 January-March 1961.

It was assumed in the past that counting of alpha particles in air ionization chambers could only be based on the collection of ions since electrons produced in the alpha track quickly form negative ions in electronegative gases. This leads to time resolutions of the order of a millisecond. It is shown in the present work that the motion of the electrons before attachment produces a sharp initial rise in the pulse profile which, although small, can be detected and utilized for high speed counting. Time resolutions of the order of a few microseconds with good signal-to-noise ratios are realized in atmospheric air, and therefore counting speeds similiar to those in nonelectronegative gases are obtained.
Neutron-insensitive proportional counter for gammaray dosimetry, R. S. Caswell, Rev. Sci. Instr. 31, No. 8, 869-871 (August 1960).

A gamma-ray dosimeter with low sensitivity to neutrons has been developed for radiation dosimetry in mixed fields of neutrons and gamma rays. Neutron sensitivity in a 2.5 $3 \mathrm{Mev} \mathrm{H}^{2}(\mathrm{~d}, \mathrm{n}) \mathrm{He}^{3}$ neutron field has been shown experimentally to be $\leq 1.2$ percent on the basis of first collision dose in tissue. Gamma-ray sensitivity is independent of energy to within \pm 5 percent from $1.25 \mathrm{Mev}\left(\mathrm{Co}^{60}\right)$ to 200 kev and to within \pm 20 percent down to $47 \mathrm{kev}$. The instrument is a proportional counter which mav be used as a dosimeter for gamma rays in the presence of neutrons by pulseheight integration of the small pulses due to secondary electrons produced by gamma rays and rejection of the large pulses due to heavy particle recoils from neutrons.

\section{Scattering of cobalt-60 gamma radiation in air ducts,} C. Eisenhauer, NBS TN\%4 (PB1615\%5) (1960) 75 cents.

The exposure dose rates due to Cobalt-60 gamma radiation scattered in small air ducts in concrete has been measured for ducts with one and two right angle bends. The inside corner of a right angle bend has been found to be an important source of scattered radiation. Results are analyzed in terms of solid angle relationships and attempts are made to extrapolate experimental results to other duct configurations.

Spatial distribution of energy dissipated by fallout beta rays, A. E. Boyd and E. E. Morris, Health Phys. 2, 321-325 (1960).

Calculations are described of the spatial distribution of energy dissipated in air by the delayed beta rays from products of slow neutron $\mathrm{U}^{235}$ fission. Results are given for both plane isotropic and point isotropic sources for times after fission of 1.12 and $23.8 \mathrm{hr}$

On the nature of the crystal field approximation, H. Goldberg and C. Herzfeld, NBS TN67 (PB161568) (1960) \$2.50

A new method is developed for the treatment of molecular interactions, and is applied to a system consisting of a hydrogen atom in a $2 \mathrm{p}$ state and a hydrogen molecule in the ground state. The interaction of these two species is calculated using ordinary crystal field theory and also the new method. A comparison of the results shows some of the shortcomings of the conventional crystal field theory, and provides corrections to it. The new method consists of (1) expanding all electron terms of the total Hamiltonian for the system which involve interactions between the atom and the molecule, thus transforming the interaction Hamiltonian into sums of products of one-electron operators, and (2) of using properly antisymmetrized wave functions made up of products of atom and molecule eigenfunctions. The calculations show the effect of the neglect of overlap and exchange in ordinary crystal field theory.

All calculations and results are presented in full detail. Transformations of three-center to two-center integrals are given explicitly.

Some experiments on the deposition of gases at $4.2^{\circ} \mathbf{K}$, T. Baurer, NBS TN73 (PB1615\% 4$)(1960)$ $\$ 1.00$.

In order to develop some preliminary information concerning the very basic problems of gaseous deposition at extremely low temperatures, samples of argon, nitrogen, oxygen, and hydrogen were deposited at $4.2^{\circ} \mathrm{K}$, and variations in some of the parameters associated with these depositions were observed. In addition, samples of the same gases were passed through an excitation zone prior to deposition, and differences in the deposition behavior were recorded. The pressure downstream of the deposition region and the temperature 
within the deposited solids were found, in general, to increase with flow rate of the depositing substances, and to vary with time in a manner depending on the density, flow rate, and state of excitation of the incoming gases. Arrhenius curves were plotted using warmup data observed in these experiments and solid-phase transition data determined elsewhere. Variations in the positions of these plots were sometimes the result of differences in the conditions of deposition, and at other times an effect of the chemical nature of the gas studied. The experimental behavior of hydrogen, relative to that of the other gases studied, was observed to be strongly dependent upon its much higher thermal conductivity.

A comment on a paper of Mori on time-correlation expressions for transport properties, M. S. Green, Phys. Rev. 119, No. 3, 829-830 (August 1960).

An auto-correlation expression given by Mori for the thermal conductivity of a fluid is shown to be only apparently different from an expression previously derived by the author.

An optical study of the boundary layer transition processes in a supersonic air system, W. Spangenberg and W. R. Rowland, Phys. of Fluids 3, No. 5 667-684 (Sept.-Oct. 1960).

A sequential-spark schlieren system with cylindrical-lens camera was used to trace the history of transition from laminar to turbulent flow on a cylindrical model in a Mach number 1.96 air stream. Both smooth and rough models were tested at several Reynolds numbers per unit length. The results showed that transition in a supersonic stream starts with high-frequency disturbances in the laminar boundary layer which degenerate into areas of turbulent How. These spots erupt independently near the trailing face of the turbulent-flow region which is always moving downstream. The addition of the newly-turbulent areas of finite size to the trailing face of the turbulent-flow region causes it to jump upstream discontinuously. Spots are traveling at a very low velocity when they first become visible, and accelerate to continue downstream at a velocity of about 0.7 times free-stream speed at their trailing face. The origin of the fresh areas of breakdown to turbulence is apparently in amplified Tollmien-Schlichting waves. The frequency of spot production lies within the region where stability theory predicts that disturbances within the boundary layer will be amplified. It is concluded that transition mechanisms in supersonic flow are similar to those in a subsonic air stream.

Temperature stratification in a non-venting liquid helium dewar, L. E. Scott, R. F. Robbins, and B. W. Birmingham, Proc. 1959 Cryogenic Engr. Conf. 5, (Sept. 2-4, 1959).

Large temperature gradients were observed in experiments conducted with a 40-liter stainless steel dewar. A method is shown for calculating the pressure rise in the non-stratifying condition and the results are compared with the observed pressure rise. An intersection of these two curves is observed and a possible explanation is given. The destratifying effects of both a concentrated heat input and of copper rods is shown.

Pressure dependence of rotationally perturbed lines in the ultraviolet band spectrum of $\mathrm{CN}, \mathrm{H}$. $\mathrm{P}$. Broida and S. Golden, Can. J. Chem. 38, 1666-1667 (1960).

Intensity measurements of the components of rotationally perturbed lines $\left(\mathrm{K}^{\prime}=4,7,11\right.$, and 15$)$ in the 0,0 transition of the violet system $\left(\mathrm{B}^{2} \Sigma^{+}-\mathrm{X}^{2} \Sigma^{+}\right)$of the CN formed in an "active" nitrogen flame have been made at pressures from 0.1 to $100 \mathrm{~mm} \mathrm{Hg}$. A simple kinetic model considering competition between formation, radiation, and collisional interchange of states gives a reasonable fit to the data over the entire range of measured pressures. At high pressures the intensity ratios of the component rotationally perturbed lines depend only upon the radiative transition probabilities and at low pressures only upon the relative rates at which they are populated. At intermediate pressures, the intensity ratios depend upon the collision frequency for the interchange of the rotationally perturbed states. The collision frequency determined in this manner is the same order of magnitude as the gas kinetic collision frequency.

Absolute isotopic abundance ratio and the atomic weight of silver, W. R. Shields, D. N. Craig, and V. H. Dibeler, J. Am. Chem. Soc. 82, 5033-5036 (1960).

An absolute value for the isotopic abundance ratio of natural silver is obtained by the use of isotopic standards prepared from nearly pure separated silver isotopes. Mass spectrometric data result in a value for the ratio, $\mathrm{Ag}^{107} / \mathrm{Ag}^{109}=$ 1.07540.0013. Within the stated limits, no variation in natural abundance is found among six samples of native silver and commercial silver nitrate. A seventh native silver sample, obtained from Cobalt, Ontario, shows a statistically significant variation. The calculated physical and chemical atomic weights of silver are $107.9028 \pm 0.001$ and $107.8731 \pm$ 0.0016 , respectively, where the indicated uncertainties are over-all limits of error based on a $95 \%$ confidence limits the mean and allowances for effects of known sources of possible systematic error.

The dynamic compressibility of a rubber-sulfur vulcanizate and its relation to free volume, J. E. McKinney, H. V. Belcher, and R. S. Marvin, Trans. Soc. Rheology IV, 347-362 (1960).

The dynamic bulk compliance of natural rubber- $12 \%$ sulfur was measured for varying static pressure (0 to 1000 bar), temperature $\left(-30\right.$ to $\left.+70^{\circ} \mathrm{C}\right)$, and frequency $(50$ to 1000 cps). The data can be represented by reduced frequency or temperature plots, assuming viscosity is proportional to $\exp (1 / \phi), \phi$ a fractional free volume which is a linear function of temperature and pressure. The temperature-frequency reduction fits the "universal" WLF constants, and the temperature-pressure reduction term is practically the same as that found by Singh and Noll for polyisobutylene.

The ionization constants of 2-chloro-4-nitrophenol and 2-nitro-4-chlorophenol, V. E. Bower and R. A. Robinson, J. Phys. Chem. 64, 1078 (1960).

Spectrophotometric measurements of 2-chloro-4-nitrophenol in succinate buffers and of 2-nitro-4-chlorophenol in phosphate buffers have been used to determine the ionization constants in aqueous solution at $25^{\circ}$. Values of $p \mathrm{~K}=5.44_{9}$ and $p \mathrm{~K}=6.45_{9}$ were respectively found.

Acid-base equilibria in benzene at three temperatures. The comparative reactivities of a phenolic acid and a carboxylic acid with triethylamine with 1,3-diphenylguanidine, M. M. Davis and M. Paabo, J. Am. Chem. Soc. 82, 5081-5084 (1960).

Equilibrium constants for the association of the phenolic indicator, bromophthalein magenta $\mathrm{E}\left(3^{\prime}, 5^{\prime}, 3^{\prime \prime}, 5^{\prime \prime}\right.$-tetrabromophenolphthalein ethyl ester), with 1,3-diphenylguanidine and with triethylamine in benzene have been determined spectrophotometrically at $20^{\circ}, 25^{\circ}$, and $30^{\circ} \mathrm{C}$.; and the association of benzoic acid with the same two bases has also been determined, using bromophthalein magenta $\mathrm{E}$ as the indicator. In all four cases the association has been assumed to conform to the equation:

$\mathrm{B}$ (base) $+\mathrm{HA}$ (acid) $\leftrightharpoons \mathrm{BH}^{+}$. . . $\mathrm{A}^{-}$(hydrogen-bonded ion-pair). 
Electron spin resonance studies of free radicals in irradiated materials, L. A. Wall, Symp. on Materials in Nuclear Application, Am. Soc. Testing Materials Spec. Tech. Publ. No. 276, 208-223 (1959).

Trapped free radicals are very often responsible for postirradiation effects. Such effects are, for example, thermal luminescence, bleaching sensitivity to oxidation and depolymerization, crosslinking, and degradation. The identification and measurement of free radicals produced by irradiation can most readily be carried out by making use of electron spin resonance (ESR). In general, the detection of simple atoms requires operation at low temperature, often as low as 4.2 $\mathrm{K}$, i.e., liquid helium. At such temperatures, atoms of hydrogen, deuterium, and nitrogen and also alkyl radicals have been found by ESR methods. On the other hand, quite high concentrations of polymer radicals with long lifetimes are found at room temperature. While the interpretation of the spectra for simple atoms is relatively simple, that of the more complex polymer radicals is much more complicated. In polymeric systems steric effects and hindrance of rotation about bonds influence the various interactions to such an extent that comparisons with model compounds of low molecular size are of little value in establishing radical structures. With all polymeric systems studied thus far, full understanding and interpretation of the ESR spectra and their behavior with temperature have not yet been achieved.

Polymer decomposition: Thermodynamics, mechanisms, and energetics, L. A. Wall, Soc. Plastic Engrs. Pt. I, 810-814 (Aug. 1960); Pt. II, 1031-1035 (Sept. 1960).

The mechanism of polymer decompositions is now at a stage where a partial understanding exists for a rather large series of polymers. However, only a few polymers have been investigated in sufficient detail to permit estimation of the activation energies and steric factors for the elementary processes. Since polymer decompositions occur in the condensed phase, assumptions that are made in gas-phase studies are not, in general, valid. Radical terminations are likely to be controlled by diffusion and hence will have relatively high activation energies. Dissociation energies for bonds in polymeric substances cannot be studied by the same techniques applicable to studies of small molecules. The "ceiling temperature" concept or thermodynamic approach, while of value for the production of polymers, is not of primary importance for thermal stability. It may be pointed out that under normal conditions polymers are metastable, and that the most thermally stable one, polytetrafluoroethylene, is the most metastable.

Heat treatment and properties of iron and steel, T. G. Digges and S. J. Rosenberg, NBS Mono. 18 (1960) 35 cents. (Supersedes C495.)

This Monograph has been prepared to give an understanding of heat treatment principally to those unacquainted with this subject. To this end, the basic theoretical and practical principles involved in the heat treatment of iron and steel are presented in simplified form.

The role of surface tension in determining certain clay-water properties, W. C. Ormsby, Bull. Am. Ceramic Soc. 39, No. 8, 408-432 (August 1960).

The importance of the surface tension of the liquid phase in controlling the plasticity and related properties of clay-water systems is critically reviewed. The experimental evidence supporting the so-called stretched membrane theory of plasticity is re-examined in some detail and is found to be incomplete. Generalizations based on this evidence are therefore open to question. Recent literature on the deformation behavior and related properties of clay-water systems suggests that wetting agents may produce ionic effects not unlike those produced by many inorganic electro- lytes. The conclusion reached is that surface tension is of secondary importance in controlling many of the properties of clay-water systems and that, when considering wetting agents or similar types of materials, specific ionic effects are of greater importance.

Comparative fixation of calcium and strontium by synthetic hydroxyapatite, R. C. Likins, H. G. McCann, A. S. Posner, and D. B. Scott, J. Biolog. Chem. 235, No. 7, 2152-2156 (July 1960).

Samples of hydroxyapatite with different crystal sizes were prepared from solutions containing radioactive calcium and strontium. Analysis of these preparations and the results of exchange studies showed a discrimination against strontium in the formation of apatite crystals which increased with crystal perfection.

\section{Other NBS Publications}

\section{Journal of Research, Section 65B, No. 1, January- March 1961. 75 cents.}

On transient solutions of the "baffled piston" problem, F. Oberhettinger.

Special types of partitioned matrices, E. V. Haynsworth.

Bound for the $p$-condition number of matrices with positive roots, P. J. Davis, E. V. Haynsworth, and M. Marcus.

Some computational problems involving integral matrices, O. Taussky.

Computational problems concerning the Hilbert matrix, J. Todd.

Index to the distributions of mathematical statistics, F. A. Haight.

Selected bibliography of statistical literature, 1930 to 1957 : IV. Markov chains and stochastic processes, L. S. Deming and D. Gupta.

\section{Journal of Research, Section 65C, No. 1, January- March 1961. 75 cents.}

Electronic scanning microscope for a spectrographic plate comparator, M. L. Kuder.

Viscoelastometer for measurement of flow and elastic recovery, R. J. Overberg and H. Leaderman.

An ultra low frequency bridge for dielectric measurements, D. J. Scheiber.

The ephi system for VLF direction finding, G. Hefley, R. F. Linfield, and T. L. Davis.

Fast counting of alpha particles in air ionization chambers, Z. Bay, F. D. MeLernon, and P. A. Newman. (See above abstract.)

X-ray diffraction measurement of intragranular misorientation in alpha brass subjected to reverse plastic strain, C. J. Newton and H. C. Vacher.

Enthalpy and specific heat of nine corrosion-resistant alloys at high temperatures, T. B. Douglas and A. C. Victor.

Determination of minor constituents in low-alloy steels by X-ray fluorescence, R. E. Michaelis, R. Alvarez, and B. A. Kilday.

Journal of Research, Section 65D, No. 2, MarchApril 1961. 70 cents.

Ionospheric motions observed with high-frequency backscatter sounders, L. H. Tveten.

Relationship between red auroral ares and ionospheric recombination, G. A. M. King and F. E. Roach. (See above abstract.)

Fresnel region fields of circular aperture antennas, Ming-Kuei $\mathrm{Hu}$.

Free-balloon borne meteorological refractometer, J. F. Theisen and E. E. Gossard.

Weather and reception level on a troposphere link-annual and short-term correlations, L. G. Abraham, Jr., and J. A. Bradshaw. 
Initial results of a new technique for investigating sferic activity, G. Hefley, R. H. Doherty, and R. F. Linfield.

Effect of antenna radiation angles upon $\mathrm{HF}$ radio signals propagated over long distances, W. F. Utlaut.

Graphic determination of radio ray bending in an exponential atmosphere, C. F. Pappas, L. E. Vogler, and P. L. Rice.

A formula for radio ray refraction in an exponential atmosphere, G. D. Thayer.

The impedance of a monopole antenna with a circular conducting-disk ground system on the surface of a lossy half-space, S. W. Maley and R. J. King.

Radio-wave propagation in the earth's crust, Harold A. Wheeler

Specific heats and enthalpies of technical solids at low temperatures. A compilation from the literature, R. J. Corruccini and J. J. Gniewek, NBS Mono. 21 (1960) 20 cents.

Amplitude-probability distributions for atmospheric radio noise, W. Q. Crichlow, A. D. Spaulding, C. J. Roubique, and R. T. Disney. NBS Mono. 23 (1960) 20 cents.

Household weights and measures, NBS Misc. Publ. 234 (1960) (Supersedes M39) 5 cents.

Screw-thread standards for federal services, 1957. Amends in part H28 (1944) (and in parts its 1950 Supplement), NBS Handb. H28 (1957)-Part III (1960) 60 cents.

Building code requirements for reinforced masonry, NBS Handb. H74 (1960) 15 cents.

Quarterly radio noise data-June, July, August 1959, W. Q. Crichlow, R. D. Disney, and M. A. Jenkins, NBS TN18-3 (PB151377-3) (1960) \$1.00.

Quarterly radio noise data-September, October, November 1959, W. Q. Crichlow, R. D. Disney, and M. A. Jenkins, NBS TN18-4 (PB151377-4) (1960) \$1.50.

Quarterly radio noise data-December, January, February 1959-60, W. Q. Crichlow, R. D. Disney, and M. A. Jenkins, NBS TN18-5 (PB151377-5) (1960) \$1.75.

Quarterly radio noise data-March, April, May 1960, W. Q. Crichlow, R. D. Disney, and M. A. Jenkins, NBS TN18-6 (PB151377-6) (1960) \$1.75.

Transistorized building blocks for data instrumentation, J. A. Cunningham and R. L. Hill, NBS TN68 (PB161569) (1960) $\$ 2.00$

Table of magnitude of reflection coefficient versus return loss $\left(L_{R}=20 \log _{10} 1 /|\Gamma|\right)$, R. W. Beatty and W. J. Anson, NBS TN72 (PB161573) (1960) \$1.25

Soviet research in field electron and ion emission, 1955-1959; an annotated bibliography, T. W. Marton and R. Klein, NBS TN75 (PB161576) (1960) \$1.25

$\mathrm{VHF}$ and UHF power generators for RF instrumentation, A. H. Morgan and P. A. Hudson, NBS TN77 (PB161578) (1960) 75 cents.

Oblique incidence receiving antenna array for a relative ionospheric opacity meter, A. C. Wilson, NBS TN78 (PB161579) (1960) 50 cents.

Our measurement system and national needs, A. V. Astin, Sperryscope 15, No. 6, 16 (1960).

Standards of heat capacity and thermal conductivity, D. C Ginnings, Book Thermoelectricity (Including Proc. Conf. Thermoelectricity, Sponsored by the Naval Research Lab. September 1958), p. 320 (1960)

A study of $2-\mathrm{Mc} / \mathrm{s}$ ionosphreic absorption measurements at high altitudes, K. Davies, J. Geophys. Research 65, 2285 (August 1960).

Carrier-frequency dependence of the basic transmission loss in tropospheric forward scatter propagation, K. A. Norton, J. Geophys. Research 65, 2029 (July 1960).

Closed circuit liquid hydrogen refrigeration system, D. B. Chelton, J. W. Dean, and B. W. Birmingham, Rev. Sci. Instr. 31, 712 (July 1960)

Infrared transmission of clouds, D. M. Gates and C. C. Shaw, J. Opt. Soc. Am. 50, 876 (September 1960).

VI. Microscopic and macroscopic energy loss distributions. 1. Theoretical reviews: A summary, U. Fano, Natl. Acad Sci., Natl. Research Council Publ. 752, Report 29, p. 24 (Aug. 1960).

The mechanical properties of ceramics and their measurement at elevated temperatures, S. J. Schneider, Book Thermoelectricity, Chapter 21, 342 (1960).
A rating method for refrigerated trailer bodies hauling perish able foods, C. W. Phillips, W. F. Goddard, Jr., and P. R. Achenbach, ASHRAE J. 2, No. 5, 45 (May 1960).

Reply to On the structure of trimethylamine-trimethylboron, D. R. Lide, Jr., J. Chem. Phys. 32, No. 5, 1570 (May 1960).

Dimensional changes occuring in dentures during processing, J. B. Woelfel, G. C. Paffenbarger, and W. T. Sweeney, J. Am. Dental Assoc. 61, No. 4, 413 (Oct. 1960).

Teeth, artificial, G. C. Paffenbarger and G. B. Denton, Eneyclopaedia Britannica 21, 878 (Jan. 1960).

A method of improving isolation in multi-channel waveguide systems, G. F. Engen, IRE Trans. Microwave Theory and Tech. Letter MTT-8, 460 (July 1960).

The characteristic energy losses of electrons in carbon, L. B. Leder and J. A. Suddeth, J. Appl. Phys. 8, 1422 (Aug. 1960).

Note historique sur les premieres annees de la microscopie electronique, L. Marton, Extrait Bull. Acad. Roy. Belg. (Classes des Sciencies) 5, 119 (Mar. 1959).

Procedure for the determination of the noble metal content of dental gold alloys, H. J. Caul., W. S. Clabaugh and M. E. Susa, J. Am. Dental Assoc. 61, No. 4, 339 (Oct. 1960).

Theory of anisotropic fluids, J. L. Ericksen, Trans. Soc. Rheology IV, 29-39 (1960).

Rapid frequency analysis of fading radio signals, J. M. Watts and K. Davies, J. Geophys. Research 65, No. 8, 2295 (Aug. 1960).

Reply to criticisms concerning Ireland contained in article "Basic research in Europe," D. M. Gates, Science 128, No. 3318, 1-9 (Aug. 1, 1958)

Modern theories of materials, C. Truesdell, Trans. Soc. Rheology IV, 9-22 (1960)

Use of the incoherent scatter technique to obtain ionospheric temperatures, T. E. VanZandt and K. L. Bowles, J. Geophys. Researsh 65, 2627 (Sept. 1960).

Highlights of the consultative committee on international radio (CCIR) activities in the field of radio propagation, J. W. Herbstreit, 9th Plenary Assembly of CCIR Proc. IRE 48, No. 1, 45 (Jan. 1960).

Graphs for bivariate normal probabilities, M. Zelen and N. C. Severo, Ann. Math. Stat. 31, No. 3, 619 (Sept. 1960).

A microwave impedance meter capable of high accuracy, R. W. Beatty, IRE Trans. Microwave Theory and Tech. MTT-8, No. 4 (July 1960).

Relaxation processes in multistate systems, K. E. Shuler, Phys. Fluids 2, No. 4, 442 (July-Aug. 1959)

Comment on models of the ionosphere above $h_{\max } \mathrm{F} 2, \mathrm{~J}, \mathrm{~W}$. Wright, J. Geophys. Research 65, 2595 (Sept. 1960).

Some magnetoionic phenomena of the Arctic E-region, J. W. Wright, J. Atmospheric and Terrest. Phys. 18, 276 (Aug. 1960).

Tables of thermodynamic and transport properties of air, argon, carbon dioxide, carbon monoxide, hydrogen, nitrogen, oxygen and steam, J. Hilsenrath, C. W. Beckett, W. S. Benedict, L. Fano, H. J. Hoge, J. F. Masi, R. L. Nuttall, Y. S. Touloukian, and H. W. Woolley, 478 pp. (Pergamon Press, Oxford, London, New York, and Paris, $1960)$.

Methods of nuclear orientation, E. Ambler, Progress in Cryogenics 2, 235-280 (Heywood \& Co., Ltd., London, England, $1960)$.

A conference on the propagation of ELF electromagnetic waves, J. R. Wait, Proc. IRE 48, 1648 (Sept. 1960).

The strength of ten structural adhesives at temperatures down to minus 424 F., W. M. Frost, Proc. 1959 Cryogenic Engr. Conf. 5, 375 (Sept. 2-4, 1959).

Possibility of detecting ionospheric drifts from the occurrence of spread $\mathrm{F}$ echoes at low latitudes, R. W. Knecht, Nature Letter 187, 927 (Sept. 1960).

Some mechanical properties of magnesium alloys at low temperatures, R. P. Reed, R. P. Mikesell and R. L. Greeson, Proc. 1959, Cryogenic Eng. Conf. 5, 397 (Sept. 2-4, 1959).

A compilation and correlation of the PVT data of normal hydrogen from saturated liquid to 80 degree K., R. B. Steward and V. J. Johnson, Proc. 1959 Cryogenic Engr. Conf. 5, 548 (Sept. 2-4, 1959).

Neighbor interactions and internal rotations in polymer molecules. IV. Solvent effect on internal rotarions, S. Lifson and I. Openheim, J. Chem. Phys. 33, No. 1, 109 (July 1960) 
Improvements in radio propagation prediction service, W. B. Chadwick, Elec. Engr. 1-4 (Sépt. 1960).

Carbon resistance themometry with mixed dc and rf currents. J. J. Gniewek and R. J. Corruccini, Rev. Sci. Inst. 31, No. 8, 899 (Aug. 1960).

Some SEAC computations of subsonic flows, P. Davis and P. Rabinowitz. Book Bergman's Linear Integral Operator Method in the Theory of Compressible Fluid Flow, by M. Z. Krsywoblocki, p. 148 (Wien, Springer-Verlag, Berlin, Germany, 1960).
Publications for which a price is indicated (except for NBS Technical Notes) are available only from the Superintendent of Documents, U.S. Government Printing Office, Washington 25, D.C. (foreign postage, one-fourth additional). Technical Notes are available only from the Office of Technical Services, U.S. Department of Commerce, Washington 25, D.C. (order by PB number). Reprints from outside journals and the NBS Journal of Research may often be obtained directly from the authors. 